\title{
DAMPAK FASILITAS IBADAH, MAKANAN HALAL, DAN MORALITAS ISLAM TERHADAP KEPUTUSAN BERKUNJUNG YANG DIMEDIASI CITRA DESTINASI WISATA
}

\author{
Oleh: \\ Agus Sudigdo \\ agus.sudigdo@gmail.com \\ Sekolah Tinggi Ilmu Ekonomi IPWI Jakarta
}

\begin{abstract}
ABSTRAK
Penelitian ini bertujuan untuk menganalisis pengaruh variabel independen, yaitu atribut Islam destinasi (fasilitas ibadah, makanan halal, moralitas Islam), pada keputusan untuk mengunjungi Jakarta turis Arab Saudi dengan citra destinasi wisata sebagai mediating variable. Data penelitian ini didasarkan pada 200 responden yang telah mengisi kuesioner tercetak, dan mereka yang pernah mengunjungi Jakarta. Metode Slovin sampling digunakan dalam penelitian ini untuk mengetahui jumlah sampel yang mewakili populasi. Metode analisis yang digunakan adalah SEM melalui perangkat lunak AMOS. Hasil penelitian menunjukkan bahwa ada pengaruh atribut Islam (fasilitas ibadah, makanan halal, moralitas Islam) pada keputusan mengunjungi Jakarta dengan citra destinasi pariwisata sebagai mediator. Saran yang diberikan, pemerintah harus mewajibkan semua pemilik bangunan/manajer untuk menyediakan ruang bagi umat Islam untuk beribadah, tempat ibadah ini harus tersedia di tempat hiburan, mal, hotel, bandara, stasiun, ruang publik, dan sebagainya. Di sisi lain, Majelis Ulama Indonesia (MUI) harus lebih agresif dalam mengawasi makanan dan minuman yang beredar di pasar. Penelitian ini tentunya memiliki beberapa keterbatasan, sehingga penelitian lebih lanjut sangat dianjurkan untuk melakukan survei atau penelitian di kota-kota lain, baik di Indonesia maupun di luar Indonesia. Selanjutnya, penelitian kualitatif dan dengan pendekatan longitudinal juga dapat dilakukan untuk peneliti masa depan untuk melihat perbedaan hasil. Akhirnya, penelitian selanjutnya disarankan untuk menganalisis variabel lain di luar model penelitian ini seperti kesetiaan destinasi dan kepuasan destinasi sebagai variabel dependen.
\end{abstract}

Kata Kunci: Fasilitas Ibadah, Makanan Halal, Moralitas Islam, Citra Destinasi Pariwisata, Keputusan Untuk Berkunjung

\section{PENDAHULUAN}

Pariwisata memiliki peran penting dalam pembangunan ekonomi nasional. Peran pariwisata di era milenium ketiga sangat penting sebagai penunjang ekonomi di luar sektor minyak dan gas baik secara nasional maupun untuk wilayah Jakarta. Dalam RPJMN (rencana lima tahun) (2015) Provinsi DKI Jakarta menempatkan sektor pariwisata sebagai prioritas ketiga setelah sektor industri dan perdagangan, meskipun ada beberapa daerah tingkat kedua untuk menentukan sektor pariwisata sebagai prioritas kedua setelah sektor pertanian. Jakarta adalah salah satu destinasi wisata (DTW) di Indonesia serta destinasi wisata lainnya seperti Bali, Jawa Barat, Sumatra dan Lombok. Untuk mencapai target kedatangan turis asing ke Indonesia sebesar 20 juta wisatawan dan pendapatan devisa sebesar US \$ 260 miliar pada tahun 2019 sangat tergantung pada destinasi wisata di Indonesia termasuk Jakarta. Jakarta adalah jumlah tamu asing terbesar kedua di antara lima provinsi 
teratas di Indonesia, pada 2016 setelah Bali. Dari 2009 hingga 2014 jumlah kedatangan turis asing ke Indonesia terus meningkat. Jumlah kedatangan wisatawan dan pendapatan devisa meningkat secara signifikan. Bahkan pada tahun 2015 sektor pariwisata telah menjadi sumber pendapatan devisa keempat terbesar setelah minyak bumi dan gas alam, batu bara, dan minyak sawit (BPS, 2015).

Perkembangan pariwisata memiliki peran penting sebagai sumber devisa, karena di sektor ini terdapat banyak peluang potensial yang dapat dimanfaatkan. Tidak seperti komoditi ekspor, pariwisata tidak dapat dikendalikan oleh proteksionisme. Juga berbeda dengan industri lain, pada dasarnya objek dan daya tarik wisata tidak akan dikonsumsi (industri tidak pernah berakhir). Beberapa negara telah membuktikan bahwa pariwisata dapat diandalkan untuk membangun kekuatan ekonomi nasionalnya. Apalagi, sebagai negara muslim terbesar di dunia, pariwisata halal memiliki peluang besar untuk dikembangkan di Indonesia.

Citra destinasi pariwisata merupakan topik utama dalam industri pariwisata untuk tujuan apa pun. Ini dapat mempengaruhi proses pengambilan keputusan pengunjung dan penjualan produk/jasa pariwisata (Tavitiyaman dan Qu, 2013). Perkembangan citra positif di benak konsumen adalah penting karena citra destinasi mampu membuat perbedaan dan menjadi faktor keberhasilan atau kegagalan suatu destinasi. Wisatawan dapat membedakan beberapa destinasi dengan menganalisis kualitas, kegiatan yang terdapat di tempat tujuan, dan ketersediaan fasilitas pendukung di suatu destinasi (Tavitiyaman dan Qu, 2013). Dalam perspektif pariwisata, konsep citra telah diakui sebagai konstruk yang terbentuk berdasarkan persepsi konsumen terkait dengan rasa, pengetahuan, dan rasa global yang memiliki korelasi dengan citra destinasi. Secara umum, ini diperoleh setelah wisatawan melakukan kunjungan ke destinasi wisata, kemudian survei dilakukan kepada para wisatawan (Pantano dan Servidio, 2011).

Turis Arab Saudi adalah pasar utama pariwisata Jakarta, oleh karena itu Jakarta harus dapat menarik sebanyak mungkin wisatawan Arab Saudi untuk datang. Menyadari hal ini, Jakarta harus dapat bersaing dengan destinasi wisata lainnya seperti Kuala Lumpur dan Singapura yang sama-sama menargetkan wisatawan Arab Saudi. Untuk memenangkan persaingan dalam perjuangan untuk wisatawan Arab Saudi, kota Jakarta mengembangkan pariwisata halal dengan menyediakan atribut destinasi Islam. Pariwisata halal adalah pariwisata yang dibuat untuk memenuhi kebutuhan wisatawan muslim. Menurut Battour et al (2011) atribut Islam di suatu destinasi terdiri dari ketersediaan tempat untuk beribadah berdasarkan keyakinan individu, makanan yang diakui halal atau bersertifikat, melarang konsumsi minuman yang mengandung alkohol, perjudian, dan menghindari konten pornografi, dan kode berpakaian wanita. Ketersediaan masjid adalah wajib sebagai atribut Islam destinasi. Jangan lupakan juga dengan kenyamanan wisatawan muslim untuk mencari makanan yang sudah terjamin halal.

\section{TUJUAN PENELITIAN}

Tujuan penelitian adalah untuk menganalisis pengaruh atribut Islam destinasi (fasilitas ibadah, makanan halal, moralitas Islam), pada keputusan untuk mengunjungi Jakarta turis Arab Saudi dengan citra destinasi wisata sebagai mediating variable.

\section{TELAAH LITERATUR DAN PENGEMBANGAN PROPOSISI/HIPOTESIS \\ Fasilitas Ibadah, Makanan Halal, dan Moralitas Islam}

Pariwisata halal adalah salah satu jenis pariwisata yang mulai dikembangkan oleh beberapa daerah dan bahkan negara di dunia. Salah satunya adalah Jakarta, Indonesia. Ini karena pemangku kepentingan pariwisata dapat melihat bahwa masih ada pasar yang belum tersentuh yang 
berpotensi menghasilkan manfaat yang menjanjikan. Meski disediakan untuk memenuhi tuntutan wisatawan muslim tetapi Pariwisata alal juga tidak menutup diri untuk wisatawan nonMuslim yang ingin merasakan budaya Islam. Karena banyak wisatawan yang mengunjungi destinasi suci untuk agama hanya untuk memenuhi rasa ingin tahu dan menambah wawasan budaya. Bukan karena turis adalah pengikut agama.

Battour dan Ismail (2014) mengungkapkan bahwa ada empat elemen yang membentuk atribut Islam. Pertama, fasilitas ibadah. Sarana ibadah yang mutlak harus memiliki fasilitas karena sudah termasuk ke dalam kebutuhan dasar wisatawan muslim. Selain itu, atribut lain seperti sosial, aspek politik, atraksi, fasilitas, dan kekayaan alam memainkan peran penting dalam mempengaruhi citra destinasi (Molina dan Gomez, 2010). Atribut destinasi pada dasarnya mengacu pada karakteristik destinasi dimana wisatawan memilih, mengidentifikasi, dan mengevaluasi kepuasan mereka. Ini termasuk iklan, pengalaman pribadi, media sosial, dari mulut ke mulut, dan sebagainya (Kotler dan Armstrong, 2018). Karakteristik suatu destinasi dapat secara signifikan mempengaruhi citra dan maksud kunjungan untuk melakukan kunjungan kembali (Chahal dan Devi, 2015).

Battour et al (2011) menyatakan bahwa atribut Islam mampu menjadi daya tarik utama bagi wisatawan Muslim, dimana ketersediaan makanan bersertifikat halal, tempat ibadah, moralitas Islam, Azan, dan lainnya ada di tempat. Aspek dasar dari moralitas Islam melibatkan kesopanan umum dengan menghindari titik-titik merah dan praktik, saluran dewasa, percampuran gratis antara pria dan wanita terutama di kolam renang dan menghitung untuk berpakaian Islam untuk wanita 'Hijab' (Battour et al, 2011; Batrawy, 2015). Battour et al (2011) melalui studinya mengungkapkan bahwa atribut Islam sangat penting untuk preferensi wisatawan Muslim dalam memilih tujuan pariwisata tertentu. Atribut Islam yang disukai adalah moralitas Islam, ketersediaan makanan bersertifikat/memiliki logo halal, dan tempat untuk beribadah, akibatnya, hipotesis berikut diusulkan:

H1: Fasilitas ibadah memiliki dampak positif pada citra destinasi wisata Jakarta

H2: Fasilitas ibadah memiliki dampak positif pada keputusan berkunjung wisatawan Arab Saudi ke Jakarta

H3: Makanan halal berdampak positif terhadap citra destinasi wisata Jakarta.

H4: Makanan halal memiliki dampak positif pada keputusan berkunjung wisatawan Arab Saudi ke Jakarta.

H5: Moralitas Islam berdampak positif terhadap citra destinasi wisata Jakarta.

H6: Moralitas Islam memiliki dampak positif pada Keputusan berkunjung wisatawan Arab Saudi ke Jakarta.

\section{Citra Destinasi Pariwisata}

Menurut Jorgensen (2004), citra destinasi dianggap sebagai "tempat tayangan" atau "area persepsi". Jorgensen menjelaskan bahwa citra positif destinasi dapat meningkatkan jumlah kedatangan wisatawan dan tentu saja mempengaruhi persepsi wisatawan. Jorgensen (2004) mendefinisikan citra destinasi tidak hanya sebagai atribut, tetapi sebagai keseluruhan citra atau kesan dari suatu destinasi. Citra destinasi terdiri dari berbagai karakteristik seperti karakteristik fungsional yang terkait dengan aspek nyata suatu destinasi dan karakteristik psikologis yang terkait erat dengan aspek tak berwujud.

Citra destinasi pariwisata dilihat sebagai anteseden langsung dari pilihan tujuan dan dibentuk sebagai hasil dari proses seleksi destinasi, dan citra destinasi pariwisata juga memainkan peran penting dalam proses dan pilihan pengambilan keputusan perjalanan. Konsep citra destinasi pariwisata umumnya digunakan untuk membuat konsep dalam riset pariwisata yang dianggap sebagai jumlah keyakinan, ide, 
dan kesan, persepsi, atau representasi mental, yang orang-orang pegang tentang wilayah geografis tertentu yang dibentuk oleh citra kognitif dari destinasi tertentu yang diberikan atas citra destinasi bisa bias atau jelas; itu dapat dibentuk di benak konsumen tanpa benar-benar mengunjungi destinasi (Hsu, Lin, \& Lee, 2017).

Citra destinasi telah banyak berkontribusi terhadap keputusan kunjungan wisatawan. Keputusan kunjungan dipengaruhi oleh citra destinasi yang dimiliki oleh tempat wisata tertentu di Iran (Abubakar \& Ilkan, 2016). Hubungan positif antara citra destinasi pariwisata dan pengambilan keputusan perjalanan telah disarankan oleh penelitian sebelumnya dari Jalilvand (2012). Dengan demikian, citra destinasi pariwisata tidak hanya mempengaruhi proses pengambilan keputusan perjalanan tetapi juga kondisi perilaku pengambilan keputusan wisatawan dengan cara bahwa dampak citra destinasi pariwisata yang positif biasanya membawa keberhasilan destinasi wisata (Han dan Kim, 2010). Chen dan Phou (2013) juga menunjukkan bahwa citra destinasi pariwisata memberikan dampak positif pada hubungan antara wisatawan dan destinasi; yang pada gilirannya mempengaruhi perilaku wisatawan. Akibatnya, hipotesis diajukan:

H7: Citra destinasi wisata Jakarta berdampak pada keputusan berkunjung wisatawan Arab Saudi ke Jakarta

\section{Keputusan Berkunjung}

Keputusan berkunjung pada umumnya dapat diartikan sebagai keputusan seorang turis untuk memilih destinasi wisata yang akan dikunjungi setelah melalui beberapa pertimbangan. Keputusan untuk mengunjungi dalam penelitian ini diadaptasi dari keputusan pembelian karena tahapan yang dilalui oleh wisatawan sama dengan tahapan yang dilalui ketika melakukan pembelian. Jang dan Feng (2007) mendefinisikan keputusan berkunjung sebagai "keputusan pengunjung tentang destinasi untuk dikunjungi dan kumpulan informasi tergantung pada tahap siklus kehidupan keluarga dari individu yang bersangkutan. Menurut Kotler dan Armstrong (2018) "Pembelian keputusan adalah keputusan yang dibuat oleh konsumen pada merek yang akan dibeli".

Dalam keputusan mengunjungi ada perbandingan pertama antara satu tujuan dengan tujuan lain. Pada akhirnya memilih tujuan yang akan dikunjungi yang dianggap memiliki kelebihan dibandingkan dengan tujuan lain. Keputusan berkunjung terjadi setelah para wisatawan melewati tahap evaluasi dari kerangka proses keputusan kunjungan. Pada tahap itu, wisatawan memiliki beberapa pilihan tujuan wisata. Yang kemudian beberapa tujuan ini dibandingkan dengan hatihati. Hingga akan muncul preferensi wisatawan ke suatu tujuan. Ini terjadi seiring dengan keinginan untuk mengunjungi destinasi wisata paling favorit. Maka langkah selanjutnya adalah aktualisasi keinginan untuk menjadi destinasi wisata. Dalam studi ini, penulis menggunakan gagasan keputusan berkunjung dari Inkson dan Minneart (2012) yang menyatakan "langkah menyangkut tindakan yang sebenarnya dari membeli produk pada harga tertentu dalam merek tertentu, dan melalui saluran distribusi tertentu". Keputusan pembelian adalah tindakan nyata untuk membeli barang atau jasa tertentu dengan harga dan merek tertentu melalui saluran distribusi.

\section{METODE PENELITIAN}

\section{Model Penelitian yang Diusulkan}

Penelitian ini telah menerapkan konsep atribut Islam oleh Battour et al (2010). Berdasarkan literatur di atas dan kerangka penelitian berikut ini dirancang untuk menunjukkan hubungan fasilitas ibadah, makanan halal, dan moralitas Islam pada keputusan mengunjungi melalui citra destinasi. Kerangka teoritis penelitian dapat dilihat pada gambar di bawah ini: 
Gambar 1

Model Penelitian yang Diajukan

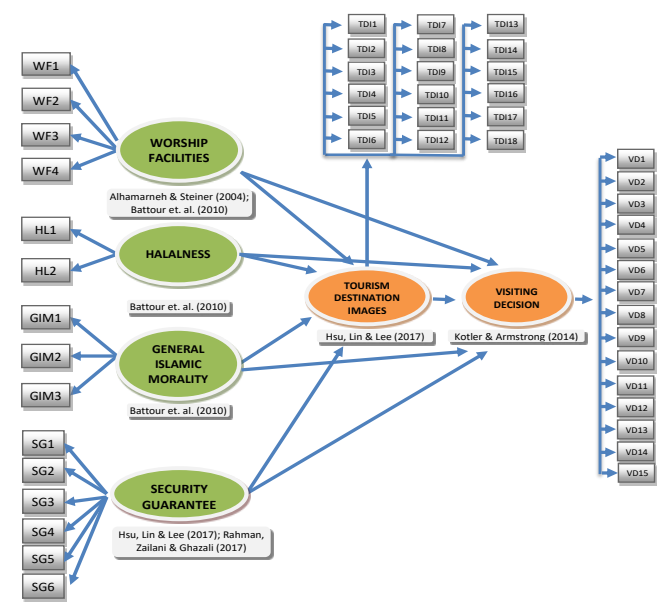

Pengembangan Instrumen

Dalam penelitian ini, ada 48 pernyataan/indikator yang digunakan. Penelitian ini menggunakan skala Likert yang umumnya digunakan dalam penelitian berbasis kuesioner (Lee, 2009). Semua variabel diukur menggunakan skala Likert 5 poin. Hasil pengolahan data menunjukkan bahwa semua indikator terbukti dapat diandalkan atau dapat diandalkan karena nilai alpha Cronbach, yang berkisar antara 0,759-0,957, semuanya lebih besar dari nilai yang direkomendasikan 0,7 (Priyatno, 2011). Temuan dalam penelitian ini juga secara konsisten mendukung pernyataan atau teori yang dikemukakan oleh Hair et. al, (2010). Hasil pengolahan data menggunakan metode CFA menunjukkan nilai pembebanan faktor lebih dari 0,50, dan nilai keandalan konstruk, dan varians diekstrak lebih dari 0,70 dan juga lebih dari 0,50, masing-masing. Dengan demikian, hasil ini menunjukkan bahwa model dalam penelitian ini layak untuk digunakan, dan setiap indikator terbukti valid atau mampu menjelaskan setiap konstruk yang digunakan dalam penelitian ini.

\section{Pengumpulan Data}

Wisatawan Arab Saudi adalah populasi dari penelitian ini. Populasi yang ditargetkan adalah sekitar 197,681 wisatawan. Ukuran sampel untuk penelitian ini didasarkan pada jumlah total wisatawan Arab Saudi yang mengunjungi Jakarta, dan data dikumpulkan menggunakan kuesioner yang dikelola sendiri. Ini didistribusikan secara pribadi kepada semua responden. Alasan utama untuk memilih pengiriman pribadi dari kuesioner ini memberikan nilai prediktif yang tinggi untuk menilai efisiensi individu di berbagai departemen, terutama ketika subjek target yang diteliti terkait dengan persepsi individu, keyakinan dan pendapat (Yalcinkaya, 2007).

Sejumlah 205 kuesioner dibagikan dan 200 set dikembalikan, dimana 200 berguna untuk analisis. Pengumpulan data total dengan jumlah minimal 200 responden karena analisis data dengan menggunakan metode SEM, yang membutuhkan minimal 200 responden (Hair et al, 2010). Mayoritas jenis kelamin responden dalam penelitian ini adalah pria, yaitu sebanyak 124 responden atau $62 \%$. Ini menunjukkan bahwa lebih dari separuh responden adalah laki-laki. Selanjutnya, latar belakang usia responden, mayoritas adalah 30-39 tahun atau 34\%. Ini menggambarkan bahwa mayoritas responden masih dalam usia produktif. Ketiga, mayoritas responden adalah warga Arab Saudi, yaitu 200 responden atau $100 \%$. Selanjutnya, mayoritas responden mengunjungi Jakarta dua kali dalam satu tahun, yaitu 72 responden atau sebesar 36\%. Jika dilihat dari segi pendapatan bulanan, mayoritas responden memiliki penghasilan $\$ 1,900-\$ 2,400$ atau $34,5 \%$. Latar belakang demografis responden lainnya, yaitu latar belakang pekerjaan dan pendidikan. Dalam penelitian ini, mayoritas responden memiliki latar belakang pekerjaan dan pendidikan, yaitu sebanyak 84 responden bekerja sebagai pedagang/ pengusaha atau sebesar $42 \%$ dan dengan latar belakang pendidikan sarjana dari 68 responden atau sebesar $34 \%$.

Selanjutnya, terkait data kunjungan wisatawan Arab Saudi, hasil penelitian menunjukkan bahwa mayoritas responden berkunjung ke Jakarta karena kebutuhan liburan, yaitu 172 
responden atau $86 \%$. Kedua, mayoritas responden mengunjungi Jakarta bersama teman-teman, yaitu $42 \%$ atau 84 responden. Dari samping, waktu yang dihabiskan oleh wisatawan Arab Saudi, mayoritas dari mereka menghabiskan waktu di Jakarta selama 3-7 hari, yaitu 69,5\%. Akhirnya, mayoritas responden mengunjungi wisata budaya saat berkunjung ke Jakarta, tercatat sebesar $46,5 \%$ atau sebanyak 93 responden.

\section{HASIL DAN PEMBAHASAN \\ Pengukuran Model Assessment dan Confirmatory Factor Analysis (CFA)}

Semua indeks goodness-of-fit melebihi tingkat penerimaan umum masing-masing seperti yang disarankan oleh penelitian sebelumnya, sehingga menunjukkan bahwa model pengukuran menunjukkan kecocokan yang baik (CFI $=0,989$, RMSEA $=0,034, \mathrm{GFI}=0,912$, AGFI $=0,884$, NFI $=0,946$, TLI $=0,987$, PNFI $=0,796$, dan PGFI $=0,695)$. Indeks kecocokan mutlak menunjukkan bahwa chi-square signifikan (nilai $\mathrm{p}>0,5$ ). Ini menunjukkan hasil uji goodness of fit dalam penelitian ini. Pertama, nilai RMSEA $\leq 0.08$ dengan hasil 0,034, maka ini dalam kategori goodness of fit. Kedua, nilai GFI dengan kriteria yang harus dicapai adalah $>0,90$, sedangkan tabel di atas menunjukkan angka 0,912, model dapat dikatakan pas. Selanjutnya, nilai NFI dengan nilai cut-off $>0,90$ dan hasil yang dicapai sama dengan 0,946, sehingga keputusan yang dicapai adalah goodness of fit.

TLI dengan nilai cut-off $>0,90$, hasil pengolahan menunjukkan nilai 0,987 , kemudian jatuh ke dalam kategori goodness of fit. Selain itu, model keseluruhan ada dalam kategori goodness of fit atau cocok untuk digunakan. Dengan demikian, penelitian ini dapat dilanjutkan pada tes berikutnya, yaitu uji hipotesis.

Membangun keandalan pada hasil pengolahan data menunjukkan nilai antara 0,759-0,957. Jadi, nilai ini di atas 0,7 (Priyatno, 2011). Selanjutnya, nilai reliabilitas komposit menunjukkan nilai antara 0,718 hingga 0,877. Nilai ini juga di atas 0,7 , sehingga dapat ditarik kesimpulan bahwa penelitian ini telah memenuhi konstruk keandalan dan reliabilitas komposit atau dengan kata lain indikator yang digunakan dalam penelitian ini dapat diandalkan, atau konsisten.

Untuk melihat tingkat validitas dalam penelitian ini, para peneliti melihat nilai faktor pembebanan yang ditemukan pada tabel di bawah ini. Semakin tinggi nilai pembebanan faktor, maka itu mewakili bahwa konstruksinya dijelaskan dengan baik oleh masingmasing indikator penelitian. Nilai pembebanan faktor lebih dari 0,50 dianggap signifikan (Hair et al, 2010). Mengacu pada tabel di bawah ini, semua indikator yang digunakan dalam penelitian ini terbukti valid atau mampu menjelaskan setiap variabel penelitian karena nilainya di atas 0,50 . Selain itu, nilai AVE untuk menguji validitas konvergen menunjukkan nilai 0,5190,643. Dengan demikian, validitas konvergen dalam penelitian ini juga telah memenuhi persyaratan karena semua memiliki nilai di atas 0,50.

\section{Model Assessment}

Goodness-of-fit dari model struktural sebanding dengan model pengukuran CFA sebelumnya. Dalam model struktural ini, nilai-nilai dicatat sebagai $\mathrm{CFI}=0,989$, dan RMSEA = 0,034. Indeks pasak ini memberikan bukti kesesuaian yang cukup antara model yang dihipotesiskan dan data yang diamati (Ghozali dan Fuad, 2008). Dengan demikian, model sekarang bisa diperiksa.

Gambar 2

Model Assesment

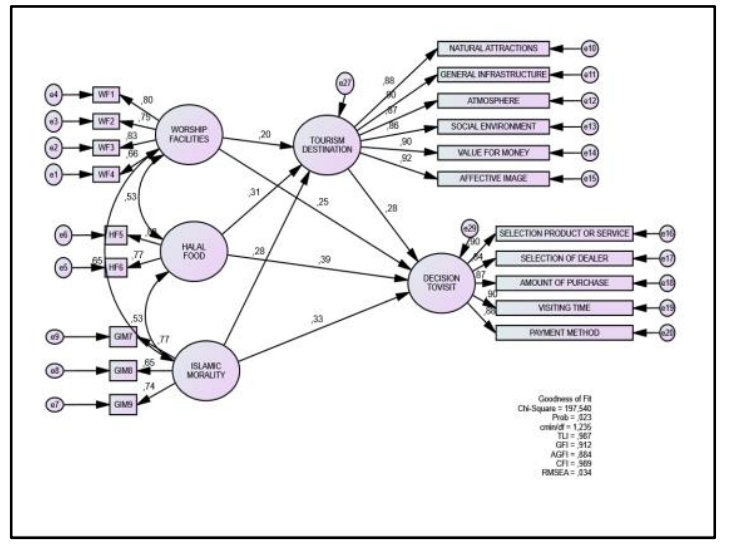




\section{Hypotheses Tests}

Hipotesis diuji menggunakan SEM melalui AMOS 23 sebagaimana disajikan pada gambar di atas. Penilaian model seperti yang ditunjukkan pada tabel 8 memberikan indikasi uji hipotesis, dan kesembilan hipotesis didukung. Hasil pengujian hipotesis pertama dan kedua menunjukkan nilai $\rho$-nilai $0,043<0,05$ dan $0,000<0,05$, sehingga hasil ini menunjukkan bahwa HO ditolak, $\mathrm{H} 1$ dan H2 diterima, yang berarti bahwa fasilitas ibadah memiliki dampak positif pada citra destinasi wisata Jakarta dan keputusan kunjungan wisatawan Arab Saudi ke Jakarta. Nilai bobot regresi standar ( $\beta$ ) menunjukkan besarnya dampak 0,199 dan 0,246 masing-masing yang berarti bahwa fasilitas ibadah memiliki dampak positif pada citra destinasi wisata Jakarta dan keputusan kunjungan wisatawan Arab Saudi ke Jakarta. Juga, hasil hipotesis ketiga dan keempat menunjukkan nilai $\rho$-value $0,000<0,05$. Hasil ini menunjukkan bahwa H0 ditolak, H3 dan H4 diterima, yang berarti bahwa makanan halal memiliki dampak positif pada citra destinasi.

Wisata Jakarta dan keputusan kunjungan wisatawan Arab Saudi ke Jakarta. Nilai bobot regresi standar $(\beta)$ menunjukkan besarnya dampak 0,310 dan 0,388 masing-masing yang berarti bahwa makanan halal memiliki dampak positif pada citra destinasi wisata Jakarta dan keputusan kunjungan wisatawan Arab Saudi ke Jakarta..

Selain itu, hasil hipotesis kelima dan keenam menunjukkan nilai $\rho$-value $0,000<0,05$, sehingga hasil ini menunjukkan bahwa HO ditolak, H5 dan H6 diterima, yang berarti bahwa moralitas Islam memiliki dampak positif pada gambar destinasi wisata Jakarta dan keputusan kunjungan wisatawan Arab Saudi ke Jakarta. Nilai bobot regresi standar ( $\beta$ ) menunjukkan besarnya dampak masing-masing 0,281 dan 0,329 yang berarti bahwa moralitas Islam memiliki dampak positif pada citra destinasi wisata Jakarta dan keputusan kunjungan wisatawan Arab Saudi ke Jakarta. Hasil hipotesis ketujuh menunjukkan nilai $\rho$-value sebesar
$0,000<0,05$, sehingga hasil ini menunjukkan bahwa HO ditolak, H7 diterima, yang berarti bahwa dan $\mathrm{H} 7$ diterima, yang berarti bahwa citra destinasi wisata Jakarta memiliki nilai positif. berpengaruh pada keputusan kunjungan wisatawan Arab Saudi ke Jakarta.

\section{Pembahasan}

Pentingnya penelitian ini selain sebagai pengetahuan konsep pariwisata Islam, hasil penelitian ini menunjukkan bahwa fasilitas ibadah, makanan halal, moralitas Islam memberikan dampak pada citra destinasi, dan wisatawan yang berkunjung, serta citra destinasi. memainkan peran penting sebagai mediator antara fasilitas ibadah, makanan halal, moralitas Islam, dan variabel keputusan berkunjung dalam penelitian ini.

Hasil penelitian ini secara konsisten mendukung penelitian sebelumnya yang dilakukan oleh Chahal dan Devi, (2015). Lingkungan yang nyaman dan ramah, suasana sejuk, berbagai atraksi, dan aksesibilitas merupakan faktor yang mampu memiliki pengaruh signifikan terhadap citra destinas. Selanjutnya, atribut lain seperti sosial, aspek politik, atraksi, fasilitas, dan kekayaan alam memainkan peran penting dalam mempengaruhi citra destinasi (Molina dan Gomez, 2010). Hari ini, wisatawan semakin sadar akan merek melalui berbagai saluran komunikasi. Ini termasuk iklan, pengalaman pribadi, media sosial, dari mulut ke mulut, dan sebagainya (Kotler dan Armstrong, 2018).

Temuan dalam penelitian ini secara konsisten mendukung teori Battour et al (2010) yang menyatakan bahwa "atribut agama Islam terikat menjadi pertimbangan yang sangat penting ketika umat Islam memutuskan untuk bepergian ke luar negeri". Sebelum bepergian, seorang Muslim akan memastikan terlebih dahulu apakah sarana ibadah yang tersedia di tempat tujuan. Dari beberapa penjelasan di atas, telah terbukti bahwa dengan atibut Islam destinasi (terutama, fasilitas ibadah) itu akan meningkatkan jumlah 
pengunjung dari wisatawan Muslim Arab Saudi ke Jakarta. Karena kemudahan untuk tetap melakukan ibadah selama liburan dijamin. Di sisi lain, atribut Islam destinasi adalah salah satu program yang dijalankan oleh pemerintah Jakarta untuk menarik lebih banyak wisatawan terutama muslim yang berasal dari Arab Saudi.

Temuan dalam hipotesis ketiga konsisten dalam mendukung penelitian sebelumnya yang dilakukan oleh Rahman et al (2015) yang mengungkapkan bahwa ada korelasi antara makanan halal atau makanan tanpa babi dengan citra destinasi. Selain itu, sifat ramah yang ditunjukkan oleh masyarakat setempat, ketersediaan berbagai pilihan makanan halal, dan harga terjangkau adalah sejumlah atribut penting dalam mempengaruhi citra destinasi wisata di Malaysia (Rahman, 2014). Sejumlah negara dikunjungi oleh wisatawan karena mereka memiliki nilai spiritual dan infrastruktur yang tinggi, dan ekonomi yang kuat (Rahman et al, 2015). Namun, bagi wisatawan Muslim, ada beberapa hal penting yang berkaitan dengan citra destinasi seperti tempat untuk beribadah, makanan bersertifikat halal, pakaian sopan yang sesuai dengan ajaran Islam, tidak adanya minuman beralkohol, fasilitas untuk wudhu, dll (Abdullah, 2012).

Hasil uji hipotesis keempat mendukung beberapa studi sebelumnya yang berkaitan dengan pengaruh makanan halal pada keputusan kunjungan wisatawan Arab Saudi ke Jakarta. Pertama, temuan ini mendukung penelitian sebelumnya yang dilakukan oleh Rahman (2014) yang mengungkapkan bahwa wisatawan Islam diperintahkan untuk mengikuti ajaran Islam yang secara langsung dan tidak langsung mempengaruhi keputusan mereka untuk mengunjungi destinasi wisata. Battour et al (2011) menyatakan bahwa atribut Islam mampu menjadi daya tarik utama bagi wisatawan Muslim, dimana ketersediaan makanan adalah bersertifikat halal, tempat ibadah, moralitas Islam, Azan, dan lainnya di tempat. Mereka mengungkapkan bahwa ketersediaan tempat untuk beribadah, makanan bersertifikat halal, tidak adanya perjudian dan minuman beralkohol di tempat tujuan, dan moralitas Islam terbukti memiliki pengaruh signifikan terhadap pilihan tujuan wisata Muslim. Mengenai pentingnya atribut Islami, Battour et al (2011) juga dengan tegas menyatakan bahwa ketersediaan fasilitas untuk beribadah bagi umat Islam, makanan halal, dan tidak adanya minuman najis, dan moralitas Islam adalah atribut Islami dari sebuah destinasi yang dapat mempengaruhi keputusan turis, seperti paket tur. Ketersediaan makanan halal merupakan kebutuhan utama di setiap tujuan wisata.

Penelitian ini secara konsisten mendukung penelitian sebelumnya di mana Han \& Kim (2010) menemukan bahwa kontrol perilaku yang dirasakan memiliki dampak positif pada gambar secara keseluruhan. Hal ini menunjukkan bahwa faktor-faktor yang menyederhanakan pelaksanaan perilaku dan persepsi faktor-faktor ini berpengaruh signifikan terhadap persepsi citra secara keseluruhan. Ketika berhubungan dengan penelitian ini, terbukti bahwa moralitas Islam sebagai kontrol perilaku yang dirasakan memainkan peran penting dalam mempengaruhi citra destinasi. Moralitas Islam adalah atribut Islam dimana penyedia layanan harus dapat menentukan destinasi wisata bagi wisatawan Muslim yang jauh dari halhal yang bertentangan dengan nilai-nilai agama Islam (Battour et al, 2013). Aspek lain yang memiliki hubungan dengan pengalaman yang didapat oleh wisatawan harus dipertimbangkan. Lingkungan di suatu destinasi harus dapat memberikan hiburan dalam konteks Islam, mematuhi semua ajaran Islam, keberadaan Azan, dan lain-lain (Battour et al, 2010).

Hubungan yang kuat dengan nilainilai Islam terbukti memiliki dampak positif pada citra destinasi. Hal ini juga sejalan dengan temuan Kim et al (2014) yang mengungkapkan bahwa preferensi wisatawan Muslim terhadap citra Islam 
adalah persepsi merek yang mempengaruhi pilihan destinasi. Penelitian ini juga mendukung studi Huang (2009) yang telah membuktikan bahwa citra destinasi sangat dipengaruhi oleh kontrol perilaku yang dirasakan. Studi ini berfokus pada pemahaman struktur dan anteseden dari niat seorang pelancong untuk mengunjungi Texas City, Amerika Serikat.

Hasil dari uji hipotesis keenam secara konsisten mendukung studi sebelumnya tentang Battour et al (2011). Mereka menjelaskan bahwa atribut Islam dapat menjadi daya tarik wisata, seperti ketersediaan tempat untuk beribadah berdasarkan keyakinan individu, dan makanan yang diakreditasi halal atau bersertifikat, melarang konsumsi minuman beralkohol, perjudian, menghindari konten pornografi, dan kode berpakaian wanita. Aspek dasar dari moralitas Islam melibatkan kesopanan umum dengan menghindari titik-titik merah dan praktik, saluran dewasa, percampuran gratis antara pria dan wanita terutama di kolam renang dan menghitung untuk berpakaian Islam untuk wanita 'Hijab' (Battour et al, 2015; Batrawy, 2015). Dengan demikian, ini menunjukkan bahwa moralitas Islam memiliki dampak positif pada Visiting Keputusan wisatawan Arab Saudi ke Jakarta. Battour et al (2011) melalui studinya mengungkapkan bahwa atribut Islam sangat penting untuk preferensi wisatawan Muslim dalam memilih destinasi pariwisata tertentu. Atribut Islam yang disukai adalah fasilitas ibadah, makanan halal, hiburan Islam, aturan berpakaian Islam dan moralitas Islam.

Hasil dari uji hipotesis ketujuh secara konsisten mendukung penelitian yang dilakukan oleh Jalilvand (2012), yang berhasil membuktikan bahwa ada dampak positif dari citra destinasi pariwisata pada pengambilan keputusan perjalanan. Hasilnya diperkuat bahwa citra destinasi memiliki dampak positif pada tujuan wisata untuk menentukan tujuan kunjungan mereka ke tempat yang indah di Iran. Dengan berbagai peneliti sebelumnya, citra destinasi adalah kesan atau ekspresi yang diperoleh oleh wisatawan dalam perjalanan mereka. Sehingga dengan citra destinasi wisata dapat mempengaruhi keputusan kunjungan ke tempat-tempat tersebut. Studi ini juga mendukung beberapa teori yang berkaitan dengan niat berkunjung wisatawan. Hsu, Lin, dan Lee (2017) mengungkapkan bahwa citra destinasi pariwisata merupakan anteseden dari pilihan destinasi. Di sisi lain, terbukti bahwa citra destinasi memainkan peran penting sebagai faktor mediasi antara atribut Islam destinasi dan keputusan perjalanan.

\section{KESIMPULAN \\ Simpulan}

- Fasilitas ibadah berpengaruh positif terhadap citra destinasi wisata kota Jakarta. Ketersediaan masjid, dan bunyi azan yang terdengar dengan jelas, serta tanda yang menunjukkan arah kiblat di sejumlah tempat seperti di kamar hotel dan masjid terbukti memberikan pengaruh pada citra Kota Jakarta sebagai destinasi wisata muslim yang memiliki citra positif.

- Fasilitas ibadah berpengaruh positif terhadap keputusan berkunjung turis Saudi Arabia ke Jakarta. Ketersediaan masjid, dan bunyi azan yang terdengar dengan jelas, serta tanda yang menunjukkan arah kiblat di sejumlah tempat seperti di kamar hotel dan masjid terbukti memberikan pengaruh pada niat turis Arab Saudi untuk mengunjungi Jakarta di masa mendatang, baik saat peak season maupun low season.

Makanan halal berpengaruh positif terhadap citra destinasi wisata kota Jakarta. Ketersediaan makanan dan minuman halal di Jakarta, serta kemudahan turis untuk mendapatkannya di Jakarta, maka hal-hal tersebut berdampak pada citra positif Kota Jakarta sebagai destinasi wisata muslim yang baik. 
- Makanan halal berpengaruh positif terhadap keputusan berkunjung turis Saudi Arabia ke Jakarta. Ketersediaan makanan dan minuman halal di Jakarta, serta kemudahan turis untuk mendapatkannya di Jakarta, maka hal-hal tersebut berpengaruh pada niat turis Arab Saudi untuk kembali mengunjungi Jakarta di masa depan.

- Moralitas Islam berpengaruh positif terhadap citra destinasi wisata kota Jakarta. Seragam yang dikenakan oleh karyawan hotel di Jakarta dinilai sangat sopan, dan masyarakat lokal mengenai pakaian sehari-hari juga cukup sopan, serta Jakarta dinilai mampu melarang prostitusi dengan tegas sehingga hal-hal tersebut memberikan pengaruh pada pembentukan citra positif Kota Jakarta sebagai destinasi wisata muslim.

- Moralitas Islam berpengaruh positif terhadap keputusan berkunjung turis Saudi Arabia ke Jakarta. Seragam yang dikenakan oleh karyawan hotel di Jakarta dinilai sangat sopan, dan masyarakat lokal mengenai pakaian sehari-hari juga cukup sopan, serta Jakarta dinilai mampu melarang prostitusi dengan tegas sehingga beberapa hal tersebut terbukti mempengaruhi niat para turis Arab Saudi untuk mengunjungi Jakarta di masa mendatang, baik saat peak season maupun low season.

- Citra destinasi wisata berpengaruh positif terhadap keputusan berkunjung turis Saudi Arabia ke Jakarta. Para turis Arab Saudi menilai bahwa Jakarta memiliki atraksi natural seperti taman, museum, dan wisata sejarah lainnya. Selain itu, mereka juga menilai bahwa masyarakat Jakarta ramah dan sangat membantu, serta terdapat banyak akomodasi dengan harga yang sangat terjangkau. Para turis Arab Saudi juga merasa tenang, senang, dan nyaman ketika berkunjung ke Jakarta. Hal-hal tersebut terbukti berpengaruh positif dan signifikan pada niat turis Arab Saudi untuk mengunjungi kembali Jakarta di masa depan.

\section{Saran}

- Pemerintah harus mewajibkan kepada semua pemilik/pengelola bangunan untuk menyediakan ruang untuk umat Muslim beribadah. Hal ini harus tersedia seperti di tempat hiburan, mal, hotel, bandara, stasiun, ruang publik, dan lain sebagainya. Selain itu, kerjasama kolektif juga dapat dilakukan oleh pemerintah dengan penyedia layanan maps electronic popular seperti Google Maps Indonesia ataupun Waze Indonesia yang bertujuan untuk secara komprehensif menampilkan petunjuk lokasi masjid atau ruang beribah bagi para penganut agama Islam, serta dapat juga menampilkan petunjuk arah kiblat di electronic maps tersebut guna mempermudah pencarian para turis Muslim.

Pemerintah dan Majelis Ulama Indonesia (MUI) harus dapat lebih agresif dalam melakukan pengawasan makanan dan minuman yang terdapat di pasar. Kedua lembaga tersebut sudah seharusnya mampu mengoptimasilasi layanan internet/website sebagai wadah untuk para produsen mensertifikasi seluruh jenis makanan dan minuman yang beredar, dari consumer goods, hingga makanan dan minuman yang terdapat di pusat perbelanjaan, mal, restoran, kafe, dan lain sebagainya. Hal ini dibutuhkan agar produk makanan dan minuman memiliki sertifikasi halal yang sesuai dengan peraturan dan hukum yang diterapkan oleh Islam melalui analisa dan penetapan yang dilakukan oleh MUI.

- Pemerintah Provinsi DKI Jakarta, khususnya Dinas Pariwisata harus melakukan sosialisasi dan standardisasi yang jelas terkait dengan seragam yang dikenakan 
oleh karyawan hotel di seluruh Jakarta. Hal ini bertujuan untuk menjaga tingkat kesopanan para karyawan hotel yang secara langsung melayani dan bertatap muka dengan para pengunjung ataupun wisatawan mancanegara. Dengan demikian, hal ini juga dapat mendukung dan membentuk citra Jakarta sebagai destinasi wisata Muslim yang ramah dan sopan.

- Integrasi transportasi publik melalui pengkomunikasian rute-rute Trans Jakarta dan moda transportasi lainnya melalui mobile application maupun website sangat perlu dilakukan. Hal ini bertujuan untuk memudahkan para wisatawan mancanegara saat ingin mengeksplorasi kota Jakarta. Selain itu, layanan transportasi publik yang aman dan nyaman terbukti mampu memberikan pengaruh positif pada peningkatan citra Jakarta sebagai destinasi muslim yang baik.

Peningkatan layanan dan keamanan di sejumlah destinasi wisata Jakarta harus dilakukan. Hal ini dapat tercipta melalui kerja sama kolektif pemerintah daerah, pihak kepolisian, dan warga setempat. Situasi yang kondusif dan aman dapat memberikan citra positif pariwisata Jakarta. Selain itu, laporan terkait keamanan selama 24 jam juga harus disediakan agar para wisatawan mancanegara dapat selalu merasa aman ketika berkunjung ke Jakarta.

- Pemerintah Provinsi DKI Jakarta harus segera membuat suatu online platform dimana platform tersebut berisis tentang seluruh informasi wisata Jakarta, tempat berolahraga, pusat hiburan, pantai, maps, lokasi untuk melakukan ibadah, museum, taman, dan juga informasi terkait akomodasi, serta info transportasi yang tersedia di Jakarta. Dengan demikian, para wisatawan mancanegara dapat dengan mudah mengakses detail informasi tersebut melalui smartphone ataupun laptop. Keterbatasan penelitian

\section{DAFTAR PUSTAKA}

Abdullah, F. 2012. The Role of Islam in Human Capital Development: a juristic analysis source: Humanomics, 28 (Issue; 1).

Abubakar, A. M \& Mustafa Ilkan. 2016. Impact of Online WOM on Destination Trust and Intention to Travel: A Medical Tourism Perspective. Journal of Destination Marketing \& Management: 1-10.

Batrawy, A. 2015. Halal Tourism on The Rise with Apps and Curtained Pool Decks. Retrieved from: http:// www.stuff.co.nz/travel/themes/fa mily/73392534/Halal-ourismn-heiseithppsndurtained-olecks. Accessed on 18/4/2018.

Battour, M., Moustafa Battor \& M. A. Bhatti. 2013. Islamic Attributes of Destination: Construct Development and Measurement Validation, and Their Impact on Tourist Satisfaction. International Journal of Tourism Research, Vol. 16: 556-564.

Battour, M \& M. N. Ismail. 2014. The Role of Destination Attributes in Islamic Tourism. SHS Web Conference.

Battour, M., M. N. Ismail \& M. Battor. 2010. The Impact of Destination Attributes on Moslem Tourist's Choice. International Journal of Tourism Research.

2011. The Impact of Destination Attributes on Moslem Tourist's Choice. International Journal of Tourism Research. Vol. 13, Iss. 6: 527-540.

BPS. Central Bureau of Statistics Jakarta. 2015.

Chahal, H \& Asha Devi. 2015. Destination Attributes and Destination Image Relationship in Volatile Tourist Destination: Role of Perceived Risk. Metamorphosis, 14(2): 1-19.

Ghozali, I \& Fuad. 2008. Structural Equation Modeling. Semarang: Universitas Diponegoro.

Hair, J. F., Black, W. C., Babin, B. J., \& Anderson, R. E. 2010. Multivariate Data Analysis (7th ed). New Jersey: Pearson. 
Han, H \& Y. Kim. 2010. An investigation of Green Hotel Customers' Decision Formation: Developing an Extended Model of the Theory of Planned Behavior. International Journal of Hospitality Management 29: 659-668.

Hsu, S. C., Chin T. Lin \& Chuan Lee. 2017. Measuring The Effect of Outbound Chinese Tourists Travel Decision-Making Through Tourism Destination Image and Travel Safety and Security. Journal of Information \& Optimization Sciences, Vol. 38 No. 3 \& 4: 559584.

Inkson, Clare \& Lynn Minnaert. 2012. Tourism Management and Introduction. India: Replika Press Pvt Ltd.

Jang, S \& R. Feng. 2007. Temporal Destination Revisit Intention: The Effects of Novelty Seeking and Satisfaction. Tourism Management, 28(2): 580-590.

Jalilvand, M. S. N. 2012. The Effect of Electronic Word of Mouth on Brand Image and Purchase Intention: An Empirical Study in The Automobile Industry in Iran. Marketing Intelligence \& Planning, Vol. 30 No. 4: 460-476.

Jorgensen, L. 2004. An Analysis of A Destination's Image and The Language of Tourism. The Aarhus School of Business.

Kotler, P \& Gary Armstrong. 2018. Principles of Marketing. Global Edition.

Lee, M. C. 2009. Factors Influencing the Adoption of Internet Banking: An Integration of TAM and TPB with Perceived Risk and Perceived Benefit. Electronic Commerce
Research and Applications, 8(3): 130-141.

Molina, A \& Mar Gómez. 2010. Tourism Marketing Information and Destination Image Management. Retrieved from: www.academicjour nals.org/journal/AJBM.

Pantano, E \& Servidio, R. 2011. An Exploratory Study of The Role of Pervasive Environments for Promotion of Tourism Destinations. Journal of Hospitality and Tourism Technology, Vol. 2 No. 1: 50-65.

Priyatno, D. 2011. Buku Saku Analisis Statistik Data SPSS. Yogyakarta: MediaKom.

Rahman, Muhammad Khalilur. 2014. Motivating Factors of Islamic Tourist's Destination Loyalty: An Empirical Investigation in Malaysia. Journal of Tourism and Hospitality Management, Vol. 2, No. 1: 63-77.

Rahman A., Ab Rahman S., Abu Samah A. Prabowo S, Abd. 2015. Revealing Factors Hindering Halal Certification in East Kalimantan Indonesia. J. Islamic Mark, 6(2): 268-291.

Tavitiyaman, Pimtong \& Hailin Qu, 2013. Destination Image and Behavior Intention of Travelers to Thailand: The Moderating Effect of Perceived Risk. Journal of Travel and Tourism Marketing, 30: 169185.

Yalcinkaya, R. 2007. Police Officers' Adoprion of Information Technology: A Case Study of The Turkish POLNET System. Unpublished Dissertation. Univesity of North Texas. 